\title{
O ideal da imparcialidade e o público cívico
}

\begin{abstract}
Uma mesa; atrás dessa mesa, que os distancia ao mesmo tempo das duas partes em litígio, estão terceiros, os juízes; a posição destes indica, primeiramente, que são neutros em relação a uma e outra; em segundo lugar, que o seu julgamento não é determinado previamente, e vai ser estabelecido depois do inquérito pela oitiva das duas partes, em função de uma certa norma de verdade e de um certo número de idéias sobre o justo e o injusto; e, em terceiro, que sua decisão terá peso de autoridade ... Ora, creio que essa idéia de que possa haver pessoas que são neutras em relação às duas partes, que possam julgá-las em função de idéias de justiça com valor absoluto, e que as suas decisões devam ser executadas, está longe demais e parece mesmo estranha à própria idéia de justiça popular.
\end{abstract}

(Michel Foucault)

Um corpo crescente de teoria moral de inspiração feminista tem questionado o paradigma do raciocínio moral, tal como é definido pelo discurso da justiça e dos direitos. Nesse paradigma, o raciocínio moral consiste na adoção de um ponto de vista imparcial e impessoal sobre uma situação, distanciado de quaisquer interesses particulares em jogo, ponderando igualmente todos os interesses e chegando a uma conclusão que esteja em

\footnotetext{
Do original "The ideal of impartiality and the civic public", publicado como capítulo 4 do livro Justice and the politics of difference (Princeton: Princeton University Press, 1990). Direitos cedidos por Princeton University Press. Traduzido por Roberto Cataldo. Revisão da tradução por Flávia Biroli.

Iris Marion Young (1949-2006) foi professora de ciência política da Universidade de Chicago, autora, entre outros livros, de Justice and the politics of difference (1990), Inclusion and democracy (2000) e Responsibility for justice (2011).
} 
conformidade com os princípios gerais da justiça e dos direitos, aplicados de forma imparcial ao caso em questão. Os críticos argumentam que esse paradigma descreve não o raciocínio moral como tal, mas o raciocínio moral específico a que se recorre em contextos públicos impessoais do Direito, da burocracia e da regulamentação da concorrência econômica. Essa "ética dos direitos" corresponde mal às relações sociais típicas da vida familiar e pessoal, cuja orientação moral não requer distanciamento, e sim envolvimento e solidariedade para com as partes específicas de uma situação; não requer princípios que se apliquem a todas as pessoas da mesma maneira, e sim uma compreensão matizada das particularidades do contexto social e das necessidades que pessoas determinadas têm e expressam dentro dele. Os filósofos deveriam reconhecer que o paradigma do raciocínio moral como aplicação imparcial de princípios gerais descreve apenas um campo limitado da vida moral; deviam, assim, desenvolver teorias morais adequadas aos contextos privados, pessoais e informais que esse paradigma ignora (Gilligan, 1982; Blum, 1980, 1988; Friedman, 1985; Noddings, 1984).

Mais recentemente, algumas teóricas feministas começaram a questionar essa oposição entre justiça e cuidado (Friedman, 1987; Okin, 1989). Neste capítulo, amplio essa linha de argumentação. As críticas feministas à teoria moral tradicional mantêm uma distinção entre papéis institucionais públicos e impessoais, aos quais se aplica o ideal da imparcialidade e da razão formal, por um lado, e relações pessoais e privadas, cuja estrutura moral é diferente, por outro. Em vez de manter essa dicotomia público/privado, essas críticas a uma ética dos direitos deveriam nos levar a questionar o próprio ideal da imparcialidade como um ideal adequado a qualquer contexto moral concreto.

Afirmo que o ideal da imparcialidade na teoria moral expressa uma lógica de identidade que procura reduzir diferenças à unidade. Só se atingem as posições de distanciamento e ausência de paixão que supostamente geram imparcialidade abstraindo-se das particularidades de situação, sentimento, filiação e ponto de vista. No entanto, essas particularidades ainda operam no contexto real de ação. Assim, o ideal da imparcialidade gera uma dicotomia entre universal e particular, público e privado, razão e paixão. É, além do mais, um ideal impossível, porque as particularidades de contexto e filiação não podem e não devem ser excluídas do raciocínio moral. Por fim, o ideal da imparcialidade cumpre funções ideológicas. Ele mascara as formas pelas quais as perspectivas particulares de grupos do- 
minantes reivindicam universalidade e colabora para justificar estruturas hierárquicas de decisão.

O ideal da razão moral imparcial corresponde ao ideal iluminista que concebe o domínio público da política como a obtenção da universalidade de uma vontade geral que deixa diferença, particularidade e corpo para trás, nos domínios privados da família e da sociedade civil. Tentativas recentes de reavivar o pensamento republicano recorrem ao ideal de um público cívico que transcende particularidades de interesse e filiação para buscar um bem comum. Antes, acompanhei esta nova iniciativa republicana ao criticar a vida pública despolitizada do pluralismo de grupos de interesse e concordei com seus defensores, no entendimento de que a política deve envolver fóruns públicos de deliberação e tomada coletiva de decisões ${ }^{1}$. Aqui, contudo, afirmo que o ideal moderno do público cívico é inadequado. O tradicional domínio público da cidadania universal tem operado para excluir pessoas associadas ao corpo e ao sentimento - principalmente mulheres, negros, índios norte-americanos e judeus. Muitos teóricos contemporâneos da democracia participativa mantêm o ideal de um público cívico no qual os cidadãos deixam para trás sua particularidade e suas diferenças. Como esse ideal universalista continua a ameaçar a exclusão de alguns, o sentido de "público" deve ser transformado para expor a positividade das diferenças de grupo, da paixão e do lúdico.

Vários autores procuraram expor e desconstruir uma lógica que encontram no discurso filosófico e teórico ocidental, que nega e reprime a diferença. Frequentemente chamados de pós-modernos, esses pensadores incluem Theodor Adorno (1973), Jacques Derrida (1976) e Luce Irigaray (1985). Seguirei Adorno ao chamar essa lógica de lógica da identidade. Para os efeitos desta exposição, considero que a crítica à lógica da identidade faz eco à crítica de Derrida a uma metafísica da presença.

A lógica da identidade expressa uma construção do sentido e das operações da razão: um ímpeto de pensar as coisas em conjunto para reduzi-las à unidade. Apresentar uma explicação racional é encontrar o universal, o princípio único, a lei, que abrange os fenômenos a serem explicados. A razão busca uma essência, uma fórmula única que classifique particulares concretos dentro ou fora de uma categoria, algo que seja comum a todas as coisas

Essa discussão é feita no capítulo 3 de Justice and the politicas of difference, capítulo que, no livro, precede o texto aqui publicado. NRT. 
que pertencem a uma categoria. A lógica da identidade tende a conceituar entidades em termos de substância e não de processo ou relação; substância é a entidade idêntica subjacente à mudança, que pode ser identificada, contada, medida.

Qualquer conceituação põe as impressões e o fluxo da experiência em uma ordem que unifica e compara, mas a lógica da identidade vai além da tentativa de ordenar e comparar as particularidades da experiência; ela constrói sistemas totalizantes em que as categorias unificadoras são, elas próprias, unificadas sob princípios, onde o ideal é reduzir tudo a um único princípio inicial.

A lógica da identidade nega ou reprime a diferença. Esta, no meu entender, designa tanto o lúdico dos eventos concretos quanto a diferenciação mutante da qual depende a significação. A razão e o discurso já estão sempre inseridos em um mundo plural, heterogêneo, que ultrapassa a compreensão totalizante. Qualquer coisa identificável pressupõe um algo mais que é o pano de fundo contra o qual ela se situa, do qual é diferenciada. Nenhuma expressão pode ter sentido a menos que se destaque, diferenciada de outra. Entendidos como diferentes, entidades, eventos e sentidos não são idênticos nem opostos. Podem ser comparados em certos aspectos, mas a semelhança não significa que sejam idênticos, e o semelhante só pode ser notado pela diferença. A diferença, no entanto, não é alteridade absoluta, ausência completa de relação ou atributos comuns.

A lógica da identidade evita a particularidade sensorial da experiência, com suas ambiguidades, e busca gerar categorias estáveis. Pela lógica da identidade, o pensamento visa a dominar essa forma de corporificação sensorial heterogênea pondo o objeto integralmente sob um conceito. Dessa forma, nega a diferença entre objeto e sujeito; procura uma unidade do sujeito pensante com o objeto pensado, em que o pensamento possa apreender, conter o real. Pela lógica da identidade, o pensamento procura pôr tudo sob seu controle, eliminar incerteza e imprevisibilidade, espiritualizar o fato corporal da imersão sensorial em um mundo que vai além do sujeito, eliminar a alteridade.

Esse projeto de reduzir a heterogeneidade das particularidades sensoriais à unidade do próprio pensamento se submete a uma lógica implacável de identidade, como se o próprio pensamento, o sujeito pensante, devesse ser reduzido à unidade. Esse sujeito é concebido como uma origem transcen- 
dental pura: não tem nenhuma base fora de si, é autogerado e autônomo. Sua pura identidade de origem garante que sua representação da realidade seja inequívoca e verdadeira. A lógica da identidade também procura reduzir a pluralidade de sujeitos determinados, sua experiência corporal, perspectiva, a uma unidade, ao julgá-los em relação ao padrão invariável da razão universal.

A ironia da lógica da identidade é que, ao procurar reduzir o diferentemente semelhante ao mesmo, transforma o meramente diferente no outro absoluto. Inevitavelmente, gera dicotomia em vez de unidade, porque o movimento para colocar particularidades sob uma categoria universal cria uma distinção entre dentro e fora. Como cada entidade ou situação particular tem semelhanças e diferenças em relação a outras entidades ou situações particulares, e elas não são totalmente idênticas nem absolutamente outras, $\mathrm{o}$ ímpeto de levá-las à unidade sob uma categoria ou princípio implica necessariamente a expulsão de algumas das propriedades das entidades ou situações. Como o movimento totalizante sempre deixa um resquício, o projeto de reduzir particularidades a uma unidade deve fracassar. Não satisfeita, então, em admitir a derrota diante da diferença, a lógica da identidade compele a diferença para oposições hierárquicas dicotômicas: essência/acidente, bom/ mau, normal/desviante.

A diferença, como o parentesco de coisas com menos ou mais semelhança em uma multiplicidade de aspectos possíveis, congela-se aqui como oposição binária $a /$ não- $a$. Em todos os casos, a unidade da categoria positiva é conseguida apenas à custa do domínio caótico do acidental, expelido e deixado de fora das explicações. Na história do pensamento ocidental, essa lógica de identidade criou um grande número dessas oposições excludentes que estruturam filosofias inteiras: sujeito/objeto, mente/corpo, natureza/cultura. Essas dicotomias no discurso ocidental são estruturadas pela dicotomia bem/ mal, puro/impuro. O primeiro lado da dicotomia é elevado acima do segundo porque designa o unificado, autoidentificado, enquanto o outro lado está fora do unificado, visto como o que é caótico, informe, em transformação, e que sempre ameaça cruzar a fronteira e romper a unidade do bem.

\section{O ideal da imparcialidade como negação da diferença}

A ética moderna estabelece a imparcialidade como a marca da razão moral. Essa concepção de razão moral pressupõe que, para escapar ao autocentrismo e atingir a objetividade, o agente deve adotar um ponto de 
vista universal, que é o mesmo para todos os agentes racionais (ver Darwall, 1983, cap. 1). O ideal da imparcialidade é o resultado dessa busca por um "ponto de vista moral" universal e objetivo. Sua concepção de razão expressa a lógica da identidade.

Como é que o teórico moral ou agente racional chega ao ponto de vista moral? Abstraindo de todas as particularidades das circunstâncias sobre as quais a razão moral reflete. Aquele que raciocina de modo imparcial é distanciado: a razão abstrai-se das experiências e histórias particulares que constituem uma situação. Também deve ser desapaixonado, abstraindo-se de sentimentos, desejos, interesses e compromissos que ele ou ela possa ter em relação à situação, ou que outros possam ter. Por fim, aquele que raciocina de modo imparcial coloca em curso um raciocínio universal. O ponto de vista moral abstrai-se da parcialidade da filiação, da perspectiva social ou de grupo, que constitui os sujeitos concretos (cf. Darwall, 1983, p. 133-143).

A razão imparcial visa à adoção de um ponto de vista exterior a situações concretas de ação, uma "visão a partir de lugar nenhum", transcendental, que não traga consigo a perspectiva, os atributos, o caráter e os interesses de qualquer sujeito ou conjunto de sujeitos particulares. Esse ideal do sujeito transcendental imparcial nega ou reprime a diferença de três maneiras. Primeiramente, nega a particularidade das situações. O sujeito que raciocina, esvaziado de toda a sua particularidade, trata todas as situações de acordo com as mesmas regras morais, e, quanto mais as regras puderem ser reduzidas a uma única regra ou princípio, mais essa imparcialidade e essa universalidade serão garantidas. Seja qual for sua situação particular, qualquer sujeito pode raciocinar a partir desse ponto de vista universal, de acordo com princípios universais que se aplicam da mesma forma a todas as situações morais.

Em segundo lugar, na sua exigência de suspensão das paixões, a imparcialidade procura dominar ou eliminar a heterogeneidade na forma de sentimento. Apenas expulsando da razão o desejo ou a afetividade é que a imparcialidade pode alcançar sua unidade. O ponto de vista imparcial é atingido por meio da abstração da particularidade concreta da pessoa na situação específica. Para isso, é necessário abstrair-se da particularidade do ser corporal, de suas necessidades e inclinações, e dos sentimentos que se vinculam à particularidade vivenciada das coisas e dos eventos. A razão normativa é definida como imparcial, e a razão define a unidade do sujeito moral, tanto no sentido de que conhece os princípios universais da 
moralidade quanto no sentido de que é o que todos os sujeitos morais têm em comum, da mesma forma. Essa razão, portanto, opõe-se ao desejo e à afetividade como o que diferencia e particulariza as pessoas.

Terceiro, a forma mais importante em que o ideal da imparcialidade reduz a particularidade à unidade é reduzindo a pluralidade dos sujeitos morais a uma subjetividade. Em sua exigência de universalidade, o ideal da razão imparcial deve representar um ponto de vista que possa ser adotado por todo e qualquer sujeito racional, precisamente pela abstração das particularidades situacionais que o individualizam. Além disso, o juiz moral imparcial, em termos ideais, deve tratar todas as pessoas da mesma forma, de acordo com os mesmos princípios, imparcialmente aplicados.

Em sua vontade de reduzir a pluralidade à unidade, a imparcialidade procura uma única subjetividade moral transcendental. A razão imparcial julga de um ponto de vista externo às perspectivas particulares de pessoas envolvidas na interação, sendo capaz de totalizar essas perspectivas em um todo, ou em uma vontade geral. A partir desse ponto de vista de um deus solitário transcendente, aquele que raciocina segundo os critérios da moral silenciosamente deduz seu juízo da ponderação das provas e alegações conflitantes e da aplicação, a elas, de princípios universais. Como já leva em conta todas as perspectivas, o sujeito imparcial não precisa levar em conta outros sujeitos que não ele próprio, a cujos interesses, opiniões e desejos deve prestar atenção.

Esse caráter monológico das abordagens filosóficas do raciocínio moral vale também para aqueles que fazem um esforço para não ignorar a pluralidade dos sujeitos morais. Rawls, por exemplo, critica o utilitarismo, alegando que ele não reconhece a pluralidade dos sujeitos morais. Por meio de sua concepção do espectador imparcial, o utilitarismo busca organizar os desejos de todas as pessoas em um sistema coerente de desejo e, assim, tornar o princípio de escolha que se aplica a uma sociedade o mesmo que se aplica aos indivíduos (Rawls, 1971, p. 26-27). Rawls afirma que sua "posição original" proporciona uma melhor representação da imparcialidade, porque "a define do ponto de vista das próprias partes em litígio. São elas que devem escolher sua concepção de justiça de uma vez por todas em uma posição original de igualdade" (Rawls, 1971, p. 190).

Enquanto Rawls insiste na pluralidade dos sujeitos como ponto de partida necessário para uma concepção de justiça, o raciocínio da posição original é, 
no entanto, monológico. Ele interpreta o processo de escolha de princípios como um jogo de negociação em que todos os indivíduos raciocinam em privado, em termos de seus próprios interesses. Esse modelo de jogo baseado na barganha de fato presume uma pluralidade de sujeitos; cada sujeito raciocina apenas em termos de seus próprios interesses, com pleno conhecimento de que há uma pluralidade de outros fazendo o mesmo, com os quais deve chegar a um acordo. As restrições ao raciocínio que Rawls insere nessa posição original a fim de torná-la uma representação de imparcialidade, no entanto, descartam não só qualquer diferença entre os que tomam parte na posição original mas também qualquer discussão entre eles. $O$ véu da ignorância retira qualquer característica diferenciadora entre os indivíduos e, assim, garante que todos raciocinem a partir de pressupostos idênticos e do mesmo ponto de vista universal. A exigência de que os participantes na posição original sejam mutuamente desinteressados impede que qualquer deles ouça a expressão dos desejos e dos interesses dos outros e seja influenciado por eles. O modelo do jogo baseado na barganha exclui a discussão e a interação genuínas entre os participantes na posição original. Para garantir que eles tenham o mínimo possível de oportunidades de interação, Rawls chega a sugerir que imaginemos um mensageiro fazendo a mediação entre eles e recolhendo propostas, anunciando-as e os informando quando tiverem chegado a um acordo (Rawls, 1971, p. 139; cf. Young, 1981).

Stephen Darwall é explícito ao dizer que as condições de imparcialidade reduzem a pluralidade dos sujeitos e dos pontos de vista obtidos na vida social real à unidade de um agente racional. $\mathrm{O}$ autor pressupõe um véu de ignorância mais espesso do que o de Rawls, que proíbe não só o conhecimento das próprias preferências, mas também a motivação por parte delas: "Suponhamos que aqueles que estão detrás do nosso véu mais espesso sejam ambos ignorantes em relação a quaisquer preferências que possam ter que não sejam comuns a qualquer agente racional como tal e, por isso, imunes à sua força motriz. Isto significa que há, na verdade, por trás do véu, apenas um sujeito que escolhe: um agente racional arbitrário" (Darwall, 1983, p. 231).

\section{A impossibilidade da imparcialidade}

A razão moral que busca a imparcialidade tenta reduzir a pluralidade de sujeitos morais e situações a uma unidade ao exigir que o julgamento moral seja distanciado, desprovido de paixões e universal. Todavia, como já sugeri, 
esse ímpeto de totalização necessariamente fracassa. Reduzir as diferenças à unidade significa colocá-las sob uma categoria universal, o que requer a exclusão daqueles aspectos das diferentes coisas que não se encaixam na categoria. A diferença se torna, assim, uma oposição hierárquica entre o que está dentro e o que está fora da categoria, valorizando mais o que está dentro do que o que ficou de fora.

A estratégia do discurso filosófico que Derrida chama de desconstrução e Adorno chama de dialética negativa expõe o fracasso da alegação de que a razão reduz a diferença à unidade. Thomas Nagel, com efeito, desconstrói a ambição da razão imparcial à totalidade. A tentativa de adotar uma perspectiva imparcial e universal sobre a realidade deixa para trás as perspectivas particulares a partir das quais se inicia, e as reconstrói como meras aparências, em oposição à realidade que a razão objetiva apreende. Contudo, a experiência dessas aparições é, em si, parte da realidade. Se a razão procura conhecer a totalidade da realidade, deve apreender todas as perspectivas particulares a partir de seus pontos de vista particulares. A imparcialidade e, portanto, a objetividade da razão dependem, no entanto, de seu distanciamento das particularidades, que devem ser excluídas de sua versão da verdade. Assim, a razão não pode conhecer o todo e não pode ser unificada (Nagel, 1986, p. 26-27).

Como outros exemplos da lógica da identidade, o desejo de construir uma razão moral imparcial resulta não em unidade, mas em dicotomia. $\mathrm{Na}$ vida moral cotidiana, antes dos movimentos totalizantes da razão universal, há apenas contextos situados de ação, com todas as suas particularidades de história, filiação e valor preconcebido. O ideal da imparcialidade reconstrói esse contexto moral, fazendo dele uma oposição entre os seus aspectos formalmente imparciais e aqueles que são meramente parciais e particulares.

A razão imparcial, como vimos, também gera uma dicotomia entre razão e sentimento. Devido à sua particularidade, o sentimento, a inclinação, as necessidades e o desejo são expulsos da universalidade da razão moral. A ausência de paixão exige abstrair-se da atração pessoal do desejo, do compromisso, do cuidado, em relação a uma situação moral, e considerá-la de forma impessoal. O sentimento e o compromisso são, assim, expulsos da razão moral; todos os sentimentos e desejos são desvalorizados, tornando-se igualmente irracionais e igualmente irrelevantes para o julgamento moral (Spraegens, 1981, p. 250-256). No entanto, esse impulso em direção 
à unidade fracassa. Sentimentos, desejos e compromissos não deixam de existir e motivar só porque foram excluídos da definição de razão moral. Eles espreitam como sombras não enunciadas, desmentindo a afirmação de abrangência da razão universalista.

Em seu projeto de reduzir a pluralidade dos sujeitos a um único ponto de vista universal, o ideal da imparcialidade gera outra dicotomia, entre uma vontade geral e interesses particulares. A pluralidade dos sujeitos não é de fato eliminada, apenas expulsa do domínio da moral; os interesses, as necessidades e os desejos concretos das pessoas e os sentimentos que as diferenciam umas das outras se tornam meramente privados e subjetivos. Na teoria política moderna, essa dicotomia aparece como aquela entre uma autoridade pública que representa o interesse geral, por um lado, e indivíduos privados com seus próprios desejos privados, não compartilháveis e incomunicáveis, por outro. Exploraremos essa dicotomia mais profundamente na próxima seção.

O ideal da imparcialidade expressa, na verdade, uma impossibilidade, uma ficção. Ninguém consegue adotar um ponto de vista que seja completamente impessoal e desprovido de paixão, completamente separado de qualquer contexto e compromissos particulares. Na busca dessa noção de filosofia da razão moral esse ideal é utópico; como expressa Nagel, a visão imparcial é uma visão a partir de lugar nenhum. Os filósofos normalmente retratam esta utopia por meio de histórias, mitos ou experiências de pensamento. Nagel diz:

Suponhamos que todas as notícias que alimentam de dados sensoriais o meu cérebro tenham sido interrompidas, mas eu, de alguma forma, tenha sido mantido respirando, nutrido e consciente. E suponhamos que se possam produzir em mim experiências auditivas e visuais não por meio de som e luz, mas por estimulação direta dos nervos, para que eu possa ser alimentado com informações em palavras e imagens sobre o que está acontecendo no mundo, o que outras pessoas viram e ouviram, e assim por diante. Nesse caso, eu teria uma concepção do mundo sem ter qualquer perspectiva a seu respeito (Nagel, 1986, p. 63).

A imaginação de Bruce Ackerman também tem um caráter de ficção científica, em certa medida. Para pensar sobre nós mesmos de um ponto de vista imparcial a partir do qual possamos formular um ideal de justiça, o autor faz com que imaginemos estar em uma nave espacial que acaba de aterrissar em um planeta no qual uma substância, o maná, pode ser convertida em qualquer coisa que qualquer pessoa possa querer. Supostamente, 
não trazemos conosco histórias e esperanças particulares, nem filiação a grupos ou religiões, e, embora Ackerman se refira a suas personagens com pronomes que têm marcas de gênero, a diferença de gênero parece não ter nenhum efeito sobre sua experiência ou seu ponto de vista. $\mathrm{O}$ trabalho desses terráqueos recém-chegados é discutir como distribuir o maná, como construir uma sociedade justa para si. Ackerman garante a imparcialidade do raciocínio que esse diálogo produz ao inserir um Comandante que serve como árbitro dialógico; ele decide - a partir de um ponto de vista imparcial, é claro - quando os falantes estão desrespeitando a única regra que orienta a discussão, ou seja, a de que ninguém pode apresentar como razão o fato de sua pessoa ou suas ideias serem melhores do que as de qualquer outra pessoa. Para chegar à imparcialidade a partir do diálogo, Ackerman tem que delimitá-lo por suas regras básicas.

Rawls nos apresenta uma ficção que não é tão chamativa, mas a posição original que ele constrói como ponto de vista da imparcialidade é igualmente utópica, principalmente em seu dispositivo do véu da ignorância. $O$ véu separa cada um de qualquer conhecimento ou conexão com uma história, um conjunto de filiações de grupo ou um conjunto de compromissos particulares; e a exigência de desinteresse mútuo garante que nada disso se desenvolva entre eles na medida em que falam. O véu "mais espesso" de Darwall, a que me referi anteriormente, é ainda mais contrafatual.

O ideal da imparcialidade é uma ficção idealista. É impossível adotar um ponto de vista moral não situado, e se o ponto de vista é situado, então ele não pode ser universal, não pode ficar à parte nem compreender todos os pontos de vista. É impossível raciocinar sobre questões morais substantivas sem compreender sua substância, que pressupõe sempre algum contexto social e histórico particular. Do mesmo modo, não há nenhuma motivação para fazer julgamentos morais e resolver dilemas morais a menos que o resultado seja importante, a menos que se tenha um interesse particular e apaixonado no resultado. Como aponta Bernard Williams, a diferença entre a reflexão factual ou científica e a reflexão prática ou moral é precisamente que a primeira é impessoal ao passo que a segunda não é:

A deliberação prática se dá, de qualquer forma, em primeira pessoa, e a primeira pessoa não é derivada nem naturalmente substituída por quem quer que seja. A ação pela qual me decido será minha, e ser minha significa não apenas que se chegará a 
ela por meio desta deliberação, mas que envolverá mudanças no mundo das quais eu serei empiricamente a causa, e da qual esses desejos e esta deliberação em si vão ser, em alguma parte, a causa (Williams, 1985, p. 68).

Alguns autores que concordam com essa crítica à dicotomia entre razão e sentimento, geral e particular, que é gerada pelo ideal tradicional da imparcialidade na teoria moral sugerem que, em vez de pensar na imparcialidade como uma visão a partir de lugar nenhum, pode-se chegar aos mesmos resultados pensando na visão que se tem a partir de todos os lugares. Susan Okin, por exemplo, reconstrói a ideia de Rawls sobre a posição original como processo de raciocínio que leva em conta todas as posições e perspectivas particulares na sociedade, a fim de chegar ao resultado justo. Ao contrário de uma abordagem kantiana mais universalista, ela sugere, essa ideia de assumir o ponto de vista de cada um não opõe razão a sentimento nem exclui o caráter particular. Com efeito, depende da capacidade de empatia do agente moral, levando em conta todas as posições e pontos de vista particulares (Okin, 1989; cf. Sunstein, 1988).

Contudo, esse movimento em direção a particularizar a imparcialidade mantém um ímpeto totalizante. As possibilidades de que se realize não são maiores que as do seu equivalente mais universalista. Permanece a ideia de que um sujeito, que seria capaz de ser imparcial, pode adotar o ponto de vista de todos os outros. Essa construção de uma noção particularista da imparcialidade pressupõe que, da minha perspectiva particular, com a minha história e experiência particulares, eu possa, mesmo assim, ter empatia com os sentimentos e perspectivas de outros que estejam diferentemente situados. Essa suposição nega a diferença entre os sujeitos. É claro que os indivíduos não são opacos uns aos outros, sua diferença não é absoluta, mas, especialmente quando classe, raça, etnia, gênero, sexualidade e idade definem posições sociais diferentes, um sujeito não pode ter uma relação de empatia completa com outro que esteja socialmente situado de maneira distinta e adotar o seu ponto de vista; se isso fosse possível, as posições sociais não seriam diferentes (cf. Friedman, 1989, p. 649-653).

Alguns podem objetar que, ao rejeitar a universalidade do ideal da imparcialidade, estou rejeitando a própria possibilidade de reflexão moral. Tal objeção se baseia na identificação da reflexão com a imparcialidade, e essa é exatamente a identificação que eu nego. A razão moral certamente exige 
reflexão, capacidade de tomar alguma distância de seus impulsos, intuições, desejos e interesses imediatos, a fim de examinar sua relação com as demandas dos outros, suas consequências se postas em prática e assim por diante. Esse processo de reflexão, no entanto, não exige que se adote um ponto de vista esvaziado das particularidades, um ponto de vista igual para todos; na verdade, é difícil ver como esse ponto de vista universal poderia contribuir para a reflexão que leva à ação em qualquer aspecto (Williams, 1985, p. 6369, 110-111; cf. Walzer, 1987, p. 48-56).

Pode-se também objetar que, ao rejeitar a universalidade do ideal da imparcialidade, eu nego a universalidade do compromisso moral, expressa no pressuposto de que todas as pessoas têm o mesmo valor moral. Nesse caso, é necessário fazer a distinção entre sentidos da universalidade. A universalidade no sentido da participação e da inclusão de todos na vida moral e social não implica a universalidade no sentido da adoção de um ponto de vista geral, que ponha de lado filiações, sentimentos, compromissos e desejos particulares. Na verdade, como argumentarei a seguir, a universalidade como generalidade operou, em muitas oportunidades, precisamente para inibir a inclusão e a participação universal (cf. Young, 1989).

A teoria moral que promove o ideal da imparcialidade começa com uma dicotomia inadequada: autocentrismo ou imparcialidade (ver Darwall, 1983, cap. 1.). Ou um agente raciocina apenas de forma autocêntrica, considerando só o que melhor promoverá os seus próprios desejos e objetivos autocentrados, ou raciocina de um ponto de vista imparcial e geral, que não tenha em vista desejos nem interesses particulares. A teoria da razão imparcial identifica erroneamente parcialidade com autocentrismo e constrói sua abstração universalista contrafatual a fim de levar o sujeito além do autocentrismo. Mas há outra maneira pela qual o sujeito vai além do autocentrismo: o encontro com outras pessoas. Um "ponto de vista moral" não surge de uma razão solitária que legisla em causa própria, mas do encontro concreto com outros, que exigem que suas necessidades, seus desejos e suas perspectivas sejam reconhecidos (cf. Levinas, 1969; Derrida, 1978). Como já afirmei, a teoria da imparcialidade pressupõe uma razão moral monológica, um único sujeito tentando sair de seu ponto de vista míope. Pressupondo-se que a razão moral seja dialógica, produto da discussão entre indivíduos situados de forma diferente, todos os quais desejam reconhecimento e validação de parte de outros, não é necessidade atingir um ponto de vista universal para 
retirar as pessoas do autocentrismo. Uma pessoa autocentrada, que se recusa a ouvir a expressão das necessidades das outras, não será, ela própria, ouvida.

A alternativa a uma teoria moral fundada no pressuposto da razão imparcial, portanto, é uma ética comunicativa. Habermas foi mais longe do que qualquer outro pensador contemporâneo na elaboração do projeto de uma razão moral que reconhece a pluralidade dos sujeitos. Ele insiste em que a subjetividade é um produto da interação comunicativa. A racionalidade moral deve ser entendida como dialógica, produto da interação de uma pluralidade de sujeitos sob condições iguais de poder, que não suprimem os interesses de qualquer um deles.

No entanto, nem Habermas parece disposto a abandonar o ponto de vista da razão normativa universal que transcende as perspectivas particularistas. Como argumenta Seyla Benhabib (1986, p. 327-351), ele hesita entre privilegiar o ponto de vista neutro e imparcial do "outro generalizado" e o que ela chama de ponto de vista do "outro concreto". Assim como as teorias de Rawls e Ackerman, uma linha da teoria de Habermas se baseia em uma concepção a priori da razão moral. A razão normativa deve ser racionalmente reconstruída, constituída por sujeitos que comecem estabelecendo um compromisso com a compreensão discursiva e com uma situação em que sejam persuadidos pelo poder do argumento mais forte. Essa motivação inicial compartilhada para se chegar ao consenso, juntamente com a suposição de uma situação de discussão que seja livre da dominação, explica como as normas morais podem ser gerais e gerar comprometimento. Como as teorias de Rawls e Ackerman, esta linha da teoria de Habermas se baseia em elementos contrafatuais que definem um ponto de partida imparcial a fim de obter a universalidade a partir do diálogo moral.

A concepção de Habermas sobre a razão dialógica considera válida apenas a manifestação de interesses generalizáveis - expressão cujo sentido é duvidoso. Às vezes, parece significar apenas aqueles interesses que são universais, que todos compartilham e que todos concordam em respeitar em relação a todos os demais. Essa interpretação dos interesses generalizáveis gera uma dicotomia entre universal e particular, público e privado, na medida em que são excluídos interesses e necessidades que podem não ser compartilhados por derivarem da história e das filiações particulares de uma pessoa,.

Outra interpretação de interesses generalizáveis, como argumenta Benhabib, deriva da ideia de que uma política emancipatória envolve a expressão 
e a interpretação de necessidades. Em uma discussão democrática na qual os participantes expressam suas necessidades, ninguém fala de um ponto de vista imparcial, nem apela a um interesse geral. Considerando-se que a satisfação das próprias necessidades depende das ações de outras na comunidade política, as pessoas são forçadas, nas palavras de Hannah Pitkin, a

reconhecer o poder de outras e apelar aos padrões de referência delas, mesmo quando tentamos levá-las a reconhecer nosso poder e nossos padrões. Somos forçados a encontrar ou criar uma linguagem comum de propósitos e aspirações, não apenas para dar a nossa perspectiva privada um disfarce público, mas por nos tornarmos conscientes, nós mesmos, de seu significado público. Somos forçados ... a transformar em "eu quero" em um "eu tenho o direito a" - uma afirmação que se torna negociável por meio de padrões de referência públicos (Pitkin, 1981, p. 347).

Nessa passagem de uma expressão de desejo a uma demanda de justiça, os participantes do diálogo não fazem uma pausa em suas situações específicas para adotar um ponto de vista universal e compartilhado. Apenas passam da necessidade de considerar os interesses próprios ao reconhecimento das demandas dos outros. Segundo essa interpretação, as alegações normativamente válidas são as generalizáveis no sentido de que podem ser reconhecidas sem violar os direitos dos outros nem submetê-los à dominação. Os interesses assim generalizáveis podem ser, ainda assim, particulares, ligados à situação e às necessidades de um grupo em particular e, portanto, não compartilhados por todos.

\section{A lógica da identidade no ideal do público cívico}

A dicotomia entre razão e desejo também aparece na teoria política moderna, na distinção entre o domínio universal e público da soberania e o Estado, por um lado, e o domínio particular e privado das necessidades e dos desejos, por outro. A teoria política e a prática política normativas modernas visam corporificar a imparcialidade no domínio público do Estado. Assim como a razão moral imparcial, esse espaço público adquire sua generalidade apenas pela exclusão da particularidade, do desejo, do sentimento e dos aspectos da vida associados ao corpo. Na teoria e na prática políticas modernas, o público cívico associado a esse domínio atinge uma unidade em particular por meio da exclusão das mulheres e de outros associados à natureza e ao corpo. 
Richard Sennett (1974) e outros autores descreveram como os centros urbanos em desenvolvimento do século XVIII engendraram uma vida pública singular. À medida que o comércio aumentava e mais pessoas vinham para a cidade, o próprio espaço da cidade foi alterado para criar mais abertura, amplas avenidas onde pessoas de diferentes classes se misturavam nos mesmos espaços (Berman, 1982). Segundo Habermas, uma das funções dessa vida pública de meados do século XVIII era fornecer um espaço crítico, onde as pessoas discutiam e criticavam os assuntos do Estado em jornais, cafés e outros fóruns (Habermas, 1974). Embora fosse dominada por homens burgueses, a discussão pública nos cafés admitia homens de qualquer classe em igualdade de condições. Além disso, por meio da instituição dos salões, bem como das sociedades de teatro e leitura, as mulheres da aristocracia e da burguesia participavam e, por vezes, assumiam a liderança na discussão pública (Landes, 1988, parte 2).

A vida pública nesse período parece ter sido turbulenta, lúdica e sexy. $\mathrm{O}$ teatro era um centro social, um fórum onde a sagacidade e a sátira desafiavam o Estado e os costumes predominantes. Esse público indomado misturava sexos e classes até certo ponto, o discurso sério com o lúdico, e a estética com a política. Não sobreviveu à filosofia republicana. A ideia do Estado universalista que expressa um ponto de vista imparcial transcendendo quaisquer interesses particulares foi, em parte, uma reação a esse público diferenciado. Os republicanos baseavam seu Estado universalista na ideia do público cívico que a teoria e a prática políticas institucionalizaram no final do século XVIII, na Europa e nos Estados Unidos, para suprimir a heterogeneidade linguística e popular do público urbano. A institucionalização cívica reordenou a vida social em uma divisão rígida entre o público e o privado.

A filosofia política de Rousseau é o paradigma desse ideal de público cívico. Ele desenvolve sua concepção de política em reação à sua experiência com o público urbano do século XVIII (Ellison, 1985), bem como em reação às premissas e conclusões da teoria atomista e individualista do Estado expressa por Hobbes. O público cívico expressa o ponto de vista universal e imparcial da razão, opondo-se ao desejo, ao sentimento e à particularidade de necessidades e interesses, e os expulsando. A partir de premissas estreitas de desejo e necessidade individuais, não podemos chegar a uma concepção normativa das relações sociais que seja forte o suficiente. A diferença entre autocentrismo atomístico e sociedade civil não consiste simplesmente no fato de que a infinidade do apetite individual foi restringida por leis aplicadas 
por meio da ameaça de punição; em vez disso, a razão aproxima as pessoas para reconhecer interesses comuns e uma vontade geral.

Para Rousseau, o povo soberano encarna o ponto de vista universal do interesse coletivo e da cidadania igual. Em sua busca de interesses individuais, as pessoas têm uma orientação particularista. Entretanto, a razão normativa revela um ponto de vista imparcial, que todas as pessoas racionais podem adotar e que expressa uma vontade geral não redutível a um agregado de interesses particulares. Participar da vontade geral como cidadão é expressar a nobreza humana e a liberdade genuína, mas esse compromisso racional com a coletividade não é compatível com a satisfação pessoal e, para Rousseau, essa é a tragédia da condição humana (Shklar, 1969, cap. 5).

Rousseau concebeu essa esfera pública como unificada e homogênea e, inclusive, sugeriu métodos para promover o compromisso com essa unidade por meio de celebrações cívicas. Embora a pureza, a unidade e a generalidade desse domínio público exijam transcender e reprimir a parcialidade e a diferenciação da necessidade, da afetividade e do desejo, custava-lhe acreditar que a vida humana pudesse e devesse existir sem a emoção e a satisfação da necessidade e do desejo. A natureza particular do homem como ser que tem necessidades e sentimentos encontra expressão no domínio privado da vida doméstica, do qual as mulheres são as guardiãs morais adequadas.

Análises feministas recentes sobre a dicotomia entre público e privado na teoria política moderna sugerem que o ideal do público cívico como imparcial e universal é, em si, suspeito. Políticos e teóricos políticos modernos proclamaram a imparcialidade e a generalidade do público e, ao mesmo tempo, muito conscientemente consideraram adequado que algumas pessoas - mais especificamente mulheres, não brancos e, às vezes, os não proprietários - devessem ser excluídas da participação nesse público. Se não foi apenas um erro, isso sugere que o ideal do público cívico como expressão do interesse geral, do ponto de vista imparcial da razão, resulta, ele próprio, em exclusão. Ao pressupor que a razão se opõe ao desejo, à afetividade e ao corpo, essa concepção de público cívico exclui aspectos corporais e afetivos da existência humana. Na prática, essa suposição impõe a homogeneidade ao público cívico, excluindo do público aqueles indivíduos e grupos que não se encaixam no modelo do cidadão racional capaz de transcender corpo e sentimento. Essa exclusão tem base dupla: a tendência a opor razão e desejo e a associação dessas características a alguns tipos de pessoas. 
No esquema social descrito por Rousseau, e por Hegel depois dele, as mulheres devem ser excluídas do domínio público da cidadania porque são as cuidadoras da afetividade, do desejo e do corpo. Permitir que apelos a desejos e necessidades corporais impulsionem debates públicos prejudicaria a deliberação pública, ao fragmentar sua unidade. Além disso, as mulheres deveriam ser dominadas também no âmbito doméstico. Sua sexualidade perigosa e heterogênea deve ser mantida casta e confinada ao casamento. Compelir as mulheres à castidade irá manter cada família como uma unidade separada, evitando o caos e a mistura de sangue que seria produzida por filhos ilegítimos. Só então as mulheres podem ser as cuidadoras adequadas do desejo dos homens, ao moderar seus impulsos potencialmente perturbadores por meio da educação moral. O desejo dos homens pelas mulheres, em si, ameaça estraçalhar e dispersar o domínio racional universal do público, bem como perturbar a distinção clara entre público e privado. Como cuidadoras do domínio privado da necessidade, do desejo e da afetividade, as mulheres devem assegurar que os impulsos dos homens não os afastem da universalidade da razão. O equilíbrio moral do coração que recebe o cuidado das mulheres moderará os impulsos possessivos individualistas do domínio particularista dos negócios e do comércio, que, como a sexualidade, ameaçam constantemente explodir a unidade da sociedade (ver Okin, 1978, parte 3; Lange, 1979; Elshtain, 1981, cap. 4; Pateman, 1988, cap. 4).

O mundo burguês instituiu uma divisão moral do trabalho entre razão e sentimento, identificando masculinidade com razão e feminilidade com sentimento e desejo (Glennon, 1979; Lloyd, 1984). A esfera da vida familiar e pessoal é uma criação moderna tanto quanto o domínio moderno do Estado e da lei, e vem como parte do mesmo processo (Nicholson, 1986, cap. 4; cf. Okin, 1981). A imparcialidade e a racionalidade do Estado dependem da contenção da necessidade e do desejo no domínio privado da família. O domínio público dos cidadãos só adquire unidade e universalidade definindo o indivíduo civil em oposição à desordem da natureza feminina, que aceita sentimento, sexualidade, nascimento e morte, os atributos que distinguem concretamente as pessoas entre si. O cidadão universal é razão (masculina) desincorporada e desapaixonada (Pateman, 1986; 1988, cap. 1-4).

O cidadão universal também é branco e burguês. As mulheres não foram as únicas pessoas excluídas da participação no público cívico moderno. Em muitos países da Europa, até recentemente, tanto judeus quanto pessoas da 
classe trabalhadora eram excluídos da cidadania. Nos Estados Unidos, os formuladores da Constituição restringiram especificamente o acesso da classe trabalhadora ao público racional e, claro, também excluíram escravos e índios da participação no público cívico. George Mosse (1985) e Ronald Takaki (1979) expõem a estrutura dessa exclusão na vida republicana burguesa na Europa e nos Estados Unidos, respectivamente. A burguesia branca masculina concebia a virtude republicana como "respeitabilidade," e o homem "respeitável” era racional, contido e casto, inflexível à paixão, aos vínculos sentimentais ou à luxúria. O homem respeitável deveria ser heterossexual, desapaixonado, regido por regras. Os aspectos corporais, sexuais, incertos e desordenados da existência nessas imagens culturais eram e são identificados com mulheres, homossexuais, negros, índios, judeus e orientais.

A ideia de nação unificada que se desenvolveu na Europa no século XIX, argumenta Mosse, dependia precisamente da oposição entre a virtude masculina e a heterogeneidade e incerteza do corpo, e de se associarem ao corpo os grupos desprezados, situando-os fora da homogeneidade da nação (cf. Anderson, 1983). Takaki mostra que os primeiros republicanos dos Estados Unidos foram bastante explícitos com relação à necessidade de homogeneidade dos cidadãos, uma necessidade que, desde os primeiros tempos da república, envolveu a relação dos republicanos brancos com os povos negros e indígenas (cf. Herzog, 1985). Esses pais republicanos, como Jefferson, identificavam as pessoas vermelhas e negras em seus territórios com a natureza selvagem e as paixões, assim como temiam que as mulheres fora do âmbito doméstico fossem licenciosas e avarentas. Eles definiam a vida republicana civilizada e moral em oposição a esse desejo retrógrado e inculto que identificavam com as mulheres e os não brancos. Mais importante, justificavam explicitamente a restrição da cidadania a homens brancos com base na ideia de que a unidade da nação dependia de homogeneidade e de razão desapaixonada.

Resumindo, o ideal de razão normativa, o sentido moral, opõe-se ao desejo e à afetividade. A razão civilizada imparcial caracteriza a virtude do homem republicano que se eleva acima da paixão e do desejo. Em vez de isolar o homem burguês inteiramente do corpo e da afetividade, no entanto, a cultura do público racional os confina à esfera doméstica, o que também confina as paixões das mulheres e oferece consolo emocional a homens e crianças. Na verdade, dentro desse âmbito doméstico, os sentimentos podem aflorar e cada indivíduo pode reconhecer e afirmar sua particularidade. 
Precisamente porque as virtudes de imparcialidade e universalidade definem o público cívico, esse público deve excluir a particularidade humana. Sendo assim, a razão normativa moderna e sua expressão política na ideia do público cívico adquirem unidade e coerência por meio da expulsão e do confinamento de tudo o que poderia ameaçar invadir a comunidade política com diferenciação: a especificidade dos corpos e do desejo das mulheres, as diferenças de raça e cultura, a variabilidade e a heterogeneidade das necessidades, dos objetivos e dos desejos dos indivíduos, a ambiguidade e a inconstância do sentimento.

\section{Funções ideológicas do ideal da imparcialidade}

Poder-se-ia objetar que eu espero demais da imparcialidade. A imparcialidade, em seu sentido mais forte, é impossível, essa objeção admite. Agentes morais reais são particulares e não podem simplesmente fazer uma pausa em suas histórias e filiações particulares, nem nos interesses práticos substanciais que estão em jogo em uma decisão. A imparcialidade deve ser entendida como um ideal regulador da razão, essa objeção afirma - irrealizável, mas importante como objetivo.

A imparcialidade não é apenas impossível, no entanto; o compromisso com o ideal da imparcialidade tem consequências ideológicas adversas. De acordo com a definição de ideologia aqui adotada ${ }^{2}$, uma ideia funciona ideologicamente quando a crença nessa ideia ajuda a reproduzir relações de dominação ou de opressão, na medida em que as justifica ou obscurece possíveis relações sociais mais emancipatórias. O compromisso generalizado com o ideal da imparcialidade cumpre pelo menos três funções ideológicas: sustenta a ideia do Estado neutro, que, por sua vez, fornece alguma base para o paradigma distributivo da justiça. Legitima a autoridade burocrática e processos decisórios hierárquicos, neutralizando demandas por processos democráticos de decisão. E, por fim, reforça a opressão apresentando o ponto de vista dos grupos privilegiados como se correspondessem a uma posição universal. Em vez de imparcialidade, afirmo, devemos buscar a justeza pública, em um contexto de heterogeneidade e discurso parcial.

A imparcialidade designa um ponto de vista que qualquer pessoa racional pode adotar, distanciado e universal, que leva igualmente em conta todos os

Remete à discussão sobre ideologia feita no capítulo 3 de Justice and the politics of difference. NRT. 
pontos de vista particulares. Quando se é imparcial ao tomar uma decisão moral ou política, essa decisão vai ser a correta, a melhor, a que de fato representa os interesses de todos os afetados, tanto quanto possível. A decisão a que chegou o agente imparcial dela encarregado é aquela a que todos os afetados teriam chegado se discutissem sob circunstâncias de respeito mútuo e igualdade de poder. Então, desde que tenhamos agentes imparciais na posição de decidir, não há necessidade de discussão.

A ideia de alguém que toma decisões de maneira imparcial funciona em nossa sociedade para legitimar uma estrutura decisória autoritária e antidemocrática. Na sociedade liberal moderna, o poder de algumas pessoas sobre outras, seu poder de tomar decisões que afetem as ações e as condições de ação de outras, não pode ser justificado com o argumento de que algumas pessoas simplesmente são melhores do que outras. Se todas as pessoas são iguais em sua capacidade de raciocínio, empatia e criatividade, e se todas têm igual valor, pode-se concluir que as decisões sobre regras e políticas que orientam sua vida conjunta devem ser tomadas por elas, coletivamente, ou seja, a soberania deve estar com o povo. No mito do contrato social, o povo delega sua autoridade a funcionários do governo, que estão encarregados de tomar decisões de forma imparcial, com um olhar apenas no interesse geral e sem o favorecimento de interesses particulares. A autonomia é coerente com a autoridade hierárquica, desde que as autoridades ajam a partir da racionalidade imparcial.

Assim, surge um aspecto diferente da dicotomia entre o domínio público do Estado e o domínio privado dos interesses parciais. O Estado está acima da sociedade, apartado e distanciado, supervisionando e arbitrando a competição e o conflito que surgem da busca privada de ganhos privados pelos indivíduos. Assim, Locke, por exemplo, usa explicitamente a metáfora de um árbitro para descrever a função do governo. O Estado toma decisões imparciais sobre as atividades da economia acumulativa e competitiva, e os cidadãos devem fidelidade e obediência a esse Estado, precisamente porque ele está supostamente numa posição imparcial, afastada de quaisquer interesses particulares (Pateman, 1979, p. 70-71).

A filosofia política de Hegel apresenta a visão mais completa e explícita do Estado como expressão de imparcialidade e universalidade contra a particularidade do desejo e do interesse. Para Hegel, a visão liberal das relações sociais baseada na liberdade que indivíduos autodefinidos têm de ir em busca 
de seus próprios objetivos descreve adequadamente apenas um aspecto da vida social, a esfera da sociedade civil. Como membro da sociedade civil, o indivíduo busca objetivos particulares para si e sua família, em associação com outros que têm interesses particulares semelhantes. Esses interesses particulares dentro da sociedade civil podem entrar em conflito, mas as transações de intercâmbio produzem muita harmonia e satisfação. Concebido como membro do Estado, por outro lado, o indivíduo não é um lócus de desejo particular, mas o portador de direitos e responsabilidades enunciados universalmente. O ponto de vista do Estado e da lei transcende todos os interesses particulares para expressar o espírito universal e racional da humanidade. As leis e a ação do Estado expressam a vontade geral, os interesses da sociedade como um todo (ver Pelczynski, 1971, p. 1-29; Walton, 1983).

Não obstante, a busca do interesse geral não é compatível com a busca de interesses particulares na mesma pessoa. Assim, deve haver uma classe distinta de cidadãos que não estão envolvidos na busca dos interesses privados na sociedade de mercado, cujo trabalho é manter o bem público e o ponto de vista universal do Estado. Esses burocratas serão escolhidos por meio de exame objetivo que identifique os mais bem qualificados para perceber e instituir o interesse geral, e estes serão sustentados com verbas do Estado para garantir sua imparcialidade. Sendo completamente independente da sociedade civil, a burocracia representa, para Hegel, a concretização social de regras morais. Sem participar de sua formação, todos os cidadãos podem ter certeza de que as leis e políticas estabelecidas pela burocracia expressam sua liberdade objetiva, a realização de sua universalidade como cidadãos e, portanto, têm um dever absoluto de respeitá-las (ver Pateman, 1979, p. 109-110; Buchanan, 1982, p. 6-10).

O poder exercido pelos funcionários do governo em nossa sociedade é legitimado por uma ideologia da imparcialidade. Não damos nenhuma ordem aos legisladores que elegemos, justamente para que possam fazer as leis de forma imparcial, as leis que refletirão o interesse geral. Essas leis são, elas próprias, imparciais, e devem se aplicar a todos da mesma forma. Com leis sábias às quais chegaram os legisladores olhando o interesse geral, executores e juízes precisam apenas aplicá-las com imparcialidade a casos particulares para que a justiça seja garantida.

De acordo com essa imagem do Estado, gestores públicos, juízes e burocratas deveriam ser os especialistas em tomar decisões imparciais. Ao 
contrário do de outras pessoas, seu trabalho não envolve imersão em atividades particulares com fins particulares; em vez disso, devem se apartar, considerar toda a diversidade de interesses e objetivos, e tomar decisões. As pessoas afetadas pelas decisões devem, por vezes, fornecer informações a juízes e burocratas em audiências e julgamentos, mas cabe à autoridade decidir o resultado, pois somente a autoridade é imparcial e representa o interesse geral. A transferência das decisões a uma assembleia popular de pessoas discutindo seus vários interesses e necessidades é certamente uma má ideia, pois criaria conflitos insolúveis. Isso porque as pessoas na sociedade civil são parciais, empenhadas em promover seu interesse próprio ou os objetivos específicos de organizações e grupos dos quais são membros, e estes estão em conflito inevitável. Como a tomada democrática de decisões não tem como funcionar, o Estado deve servir como um árbitro neutro.

A ideia do Estado neutro, acima dos interesses e dos conflitos particulares da sociedade civil é, no entanto, um mito. As críticas marxistas ao Estado liberal também se aplicam a essa imagem do Estado como árbitro na competição entre grupos de interesse. Se existem diferenças significativas de poder, recursos, acesso a informações e assim por diante, entre diferentes classes, grupos ou interesses, os procedimentos de tomada de decisão que são imparciais, no sentido de permitir igual oportunidade formal para que todos pressionem por seus interesses, geralmente produzirão resultados no interesse dos mais poderosos.

Além disso, a imparcialidade é tão impossível para os burocratas que tomam decisões quanto para os outros agentes morais. É simplesmente impossível para os tomadores de decisão de carne e osso, estejam eles no governo ou não, adotar o ponto de vista da razão transcendental quando tomam decisões, divorciando-se de filiações e compromissos de grupo que constituem suas identidades e definem sua perspectiva da vida social. Mas não se conclui, a partir da particularidade de suas histórias e seus interesses, que as pessoas sejam capazes de considerar apenas a si mesmas, que sejam incapazes e sem disposição para levar em consideração outros interesses e pontos de vista. A ideologia pluralista que define os interesses econômicos e sociais como sendo puramente interesses próprios e o Estado como imparcial, no entanto, encoraja a pensar apenas em termos de interesse próprio. Cada um deve pressionar por seus interesses, e o Estado imparcial vai garantir que a justiça seja feita. Já argumentei que ser justo não requer deixar de ser 
quem se é. A história e os compromissos de uma pessoa ou grupo são parciais precisamente porque elas nunca contêm, do exterior, todos os pontos de vista relevantes. Legisladores, gestores públicos e outros funcionários de governo também desenvolvem, costumeiramente, uma visão parcial da vida social e um conjunto de interesses particulares que derivam de seu contexto no governo; na verdade, o governo não transcende a sociedade civil para vê-la em sua totalidade (Noedlinger, 1981).

O mito do Estado neutro cumpre uma função ideológica na medida em que ajuda a reforçar o paradigma da justiça distributiva. A maioria das discussões sobre a justiça pressupõe, implícita ou explicitamente, que ela seja aplicada por uma autoridade e que esta autoridade seja imparcial. A maioria das discussões sobre justiça social também pressupõe que as questões de justiça digam respeito exclusiva ou principalmente aos princípios que devem guiar a política do governo. Se a reflexão sobre a justiça pressupõe o estado como um domínio imparcial de decisão que transcende e inclui todos os interesses, perspectivas e compromissos parciais, então as únicas questões significativas de justiça são distributivas. Se assumirmos que quem a aplica é imparcial e, portanto, leva em consideração todos os interesses da sociedade, não há razão para transformar em questão relevante a organização justa do poder de decisão.

O ideal da imparcialidade, já argumentei, legitima a autoridade burocrática. Isso se aplica tanto à autoridade em uma empresa ou organização privada quanto ao governo. Também nesse sentido, a autoridade se justifica não por motivos aristocráticos, mas em razão de uma necessidade de separar as tarefas de gestão das outras, fazendo com que os gestores supervisionem as perspectivas diferentes e parciais sobre a organização. Tendo o gestor subido na hierarquia de uma organização porque a inteligência, a criatividade o esforço dele e, de vez em quando, dela, demonstrou seu mérito, sua tarefa é supervisionar os subordinados de forma "profissional", o que significa assumir o ponto de vista da razão objetiva e imparcial ao tomar decisões. As regras de uma empresa ou agência devem ser, elas próprias, imparciais e formais, e o gestor deve aplicá-las com imparcialidade. Suas decisões devem refletir os interesses da organização como um todo. A hierarquia burocrática é justa porque as posições são atribuídas de modo imparcial, de acordo com o mérito. Contanto que os tomadores de decisão se esforcem para atingir a imparcialidade, a democracia é desnecessária; suas decisões atenderão aos 
interesses de todos. Assim sendo, o ideal da imparcialidade ajuda a legitimar a organização hierárquica da maioria dos locais de trabalho e a ideia de alocação de mérito de seus cargos. Em outro momento eu me dedico à crítica ao mito da meritocracia ${ }^{3}$, que pressupõe a possibilidade de padrões de avaliação que sejam normativa e culturalmente imparciais.

A insistência no ideal da imparcialidade, mesmo sendo ele impossível de atingir, funciona para mascarar a inevitável parcialidade de perspectiva que de fato orienta a deliberação moral. As premissas e os compromissos situados que derivam de histórias, experiências e filiações particulares se apressam para preencher o vácuo criado pela abstração contrafatual; mas, agora, são afirmados como pressupostos “objetivos" sobre a natureza humana ou a psicologia moral. O ideal da imparcialidade gera uma propensão a universalizar o particular.

Onde existem diferenças entre grupos sociais e alguns grupos são privilegiados, enquanto outros são oprimidos, essa propensão a universalizar o particular reforça a opressão. O ponto de vista dos privilegiados, sua experiência e seus padrões particulares, são interpretados como normais e neutros. Se a experiência de alguns grupos difere dessa experiência neutra, ou se eles não estão à altura dos padrões de referência, essa diferença é interpretada como desvio e inferioridade. Nesse caso, não apenas a experiência e os valores dos oprimidos são ignorados e silenciados mas também são prejudicados por suas identidades situadas. Para que essa situação seja injusta, não é necessário que os privilegiados estejam egoisticamente em busca de seus próprios interesses em detrimento dos de outros. Sua forma parcial de interpretar as necessidades e os interesses dos outros, ou de ignorá-los de forma não intencional, é suficiente. Se os grupos oprimidos questionarem a suposta neutralidade dos pressupostos e políticas vigentes e expressarem suas próprias experiências e perspectivas, suas reivindicações serão tomadas como a expressão de interesses especiais enviesados e egoístas, que se desviam do interesse geral imparcial. O compromisso com o ideal da imparcialidade, portanto, torna difícil expor a parcialidade do ponto de vista supostamente geral e reivindicar que os oprimidos sejam ouvidos.

O ideal da imparcialidade legitima as hierarquias no processo decisório e permite que o ponto de vista dos privilegiados apareça como universal.

Essa crítica é o foco da autora no capítulo 7 de Justice and the politics of difference. NRT. 
A combinação dessas funções muitas vezes leva a decisões concretas que perpetuam a opressão e a desvantagem de alguns grupos e o privilégio de outros. As posições de autoridade nos locais em que as decisões são tomadas são, geralmente, ocupadas por membros dos grupos privilegiados - homens brancos, de origem anglo-saxônica, nominalmente heterossexuais - já que o acesso a essas posições faz parte de seu privilégio. Com base em suposições e padrões que afirmam ser neutros e imparciais, as suas decisões autorizadas muitas vezes calam, ignoram e tornam desviantes as capacidades, necessidades e normas de outros. A solução para a dominação e a opressão que se seguem é desmantelar a hierarquia. Se a razão normativa é dialógica, há mais probabilidades de surgirem normas justas a partir da interação real de pessoas com diferentes pontos de vista que têm que olhar para fora de si mesmas ao serem forçadas a confrontar e ouvir as outras. As estruturas de decisão justas devem, portanto, ser democráticas, garantindo voz e voto a todos os grupos particulares envolvidos nessas decisões e por elas afetados.

\section{Democracia participativa e a ideia de um público heterogêneo}

Se abrimos mão do ideal da imparcialidade, não resta justificativa moral para processos de tomada de decisão com relação à ação coletiva que não sejam democráticos. Em vez de um contrato fictício, exigimos estruturas de participação verdadeiras, nas quais pessoas reais, com suas diferenças geográficas, de gênero, étnicas e profissionais, afirmam suas perspectivas sobre questões sociais dentro das instituições que incentivam a representação de suas distintas vozes. O debate teórico sobre justiça requer, portanto, uma discussão teórica sobre a democracia participativa. Como salienta Carole Pateman (1986), no entanto, muitos teóricos contemporâneos da democracia participativa não são menos comprometidos com o ideal do público cívico que seus precursores clássicos.

Esse ideal do público cívico, como afirmei, exclui as mulheres e outros grupos definidos como diferentes, porque seu status racional e universal deriva apenas de sua oposição à afetividade, à particularidade e ao corpo. Os teóricos republicanos insistiram na unidade do público cívico: na medida em que se define como cidadão, cada homem deixa para trás sua particularidade e sua diferença, para adotar um ponto de vista universal, idêntico para todos os cidadãos - o ponto de vista do bem comum ou da vontade geral. Na prática, os políticos republicanos garantiram a homoge- 
neidade excluindo da cidadania todos aqueles definidos como diferentes e associando a corpo, desejo ou necessidade influências que possam desviar os cidadãos do ponto de vista da razão pura. Dois teóricos contemporâneos da democracia participativa, Benjamin Barber e Jürgen Habermas, mantêm características importantes do ideal universalista do público cívico, embora ambos o façam de forma ambígua.

Barber (1984) argumenta ferozmente contra teóricos políticos contemporâneos que constroem um modelo de discurso político purificado das dimensões afetivas. Ritual, mito, paixão, expressão emocional e discurso poético têm sentido político, argumenta ele, tanto quanto a argumentação racional. Assim, Barber não teme o rompimento da unidade e da racionalidade do público pelo desejo e o corpo, como parecem temer vários teóricos republicanos, mas sustenta, em seu conceito de democracia forte, uma concepção de público cívico definido pela unidade e pela universalidade, ao contrário da afinidade de grupo e de necessidades e interesses particulares. Ele faz uma clara distinção entre o domínio público da cidadania e da atividade cívica, por um lado, e o domínio privado das identidades, papéis, filiações e interesses particulares, por outro. A democracia forte, o autor afirma, lamenta qualquer divisão no público, que, em termos ideais, expressa uma vontade comum e um julgamento comum de todos os cidadãos. A cidadania de forma nenhuma esgota as identidades sociais das pessoas, mas tem prioridade moral sobre todas as outras atividades sociais na democracia forte. A busca de interesses particulares, a pressão das reivindicações dos grupos determinados, tudo isso deve acontecer dentro de uma moldura de comunidade e visão comum estabelecida no domínio público. Assim, a visão de Barber sobre democracia participativa continua a se basear em uma forte oposição entre a esfera pública da cidadania e a esfera privada de interesses e filiações particulares. O processo de democracia participativa, para ele, requer a suspensão das diferenças sociais, que, segundo afirmei, tende a levar ao privilégio de alguns grupos cujas vozes e perspectivas dominam o público supostamente comum.

A teoria da ação comunicativa de Habermas é mais ambígua do que a de Barber no que diz respeito ao grau em que mantém o legado republicano de unidade e de universalismo em sua definição do público como um domínio da razão, oposto a um domínio privado de desejo e sentimento. Como afirmei anteriormente, as principais tendências de uma teoria da ação comunicativa 
levam a uma democracia participativa genuinamente intersubjetiva e contextual. Sem o ponto de vista transcendental da imparcialidade, só se pode fundamentar a racionalidade das normas entendendo-as como resultado da discussão, incluindo todos aqueles que serão sujeitos a elas. Uma possível interpretação da ética comunicativa é que as reivindicações normativas são o resultado da expressão de necessidades, sentimentos e desejos que os indivíduos reivindicam que tenham sido atendidos e reconhecidos pelos outros, em condições nas quais todos têm voz igual na expressão de suas necessidades e de seus desejos. Essa interpretação, portanto, tende a desmontar a distinção entre razão pública e um domínio privado de desejo, necessidade e sentimento.

Porém, uma forte vertente do universalismo kantiano permanece em Habermas, o que prejudica esse movimento em direção a uma política participativa radicalmente pluralista de interpretação da necessidade. Habermas mantém vestígios da dicotomia entre razão e afetividade. Ele separa de forma bastante firme o discurso sobre sentimentos do discurso sobre normas. Seu modelo da própria linguagem, além disso, depende muito de um paradigma de argumentação discursiva, retirando a ênfase aos aspectos metafóricos, retóricos, lúdicos e corporificados da fala que são um aspecto importante do seu efeito comunicativo (ver Young, 1987; cf. Keane, 1984, p. 169-172). Apesar das possibilidades de uma ética comunicativa, o próprio Habermas mantém um compromisso com o "ponto de vista moral", como o de um "outro generalizado", no qual o sujeito que raciocina abstrai-se de seus próprios contextos concretos de necessidade, desejo e compromisso, e considera os outros também a partir desse ponto de vista geral. Dessa forma, mantém uma distinção entre um domínio público de direitos e princípios e um domínio privado de necessidade contextualizada (Benhabib, 1986, p. 348-351). Por fim, a alegação de que os participantes do diálogo implicitamente buscam o consenso é uma reminiscência da unidade ideal do público cívico.

Como discutido antes, muitos autores afirmam que a sociedade corporativa do bem-estar é despolitizada por meio da institucionalização do pluralismo de grupos de interesse ${ }^{4}$. Assim como Barber demanda um público democrático forte, muitos desses autores também demandam a reinstituição de um público cívico em que os cidadãos transcendam seus

Essa discussão foi feita pela autora no capítulo 3 de Justice and the politics of difference. NRT. 
contextos, necessidades e interesses particulares para atender o bem comum. Venho afirmando, no entanto, que esse desejo de unidade política suprime a diferença e tende a excluir, do público, algumas vozes e perspectivas, porque o privilégio e a posição dominante de alguns grupos permite que eles formulem o "bem comum" em termos influenciados por sua perspectiva e seus interesses particulares.

Contrariamente à descrição de Barber, por exemplo, o problema do pluralismo baseado nos grupos de interesse não é que ele seja plural e particular, mas que seja privatizado. Institucionaliza e incentiva uma visão do processo político que é egoísta e centrada no interesse próprio; cada parte entra na concorrência política por bens e privilégios escassos apenas para maximizar seu próprio ganho, e não precisa ouvir nem responder às reivindicações de outros pelo seu próprio bem. Assim, o pluralismo de grupos de interesse dá pouco espaço a afirmações de que algumas partes têm a responsabilidade de atender às reivindicações de outras, porque estas são necessitadas e oprimidas. Os processos e, muitas vezes, os resultados da negociação entre grupos de interesse ocorrem, ainda, em grande parte privadamente, não sendo revelados nem discutidos em um fórum que realmente inclua todos os potencialmente afetados pelas decisões.

A repolitização da vida pública não exige a criação de um domínio público unificado no qual os cidadãos deixem para trás suas filiações de grupo, histórias e necessidades particulares para discutir um mítico "bem comum". Em uma sociedade diferenciada por grupos sociais, profissões, posições políticas, diferenças de privilégio e opressão, regiões e assim por diante, a percepção de qualquer coisa como um bem comum só pode ser resultado da interação pública que expressa particularidades em lugar de suspendê-las. Aqueles que buscam a democratização da política em nossa sociedade, em minha opinião, devem reconceituar o significado do público e do privado e a relação entre eles, para romper decididamente com a tradição do republicanismo iluminista. Embora haja boas razões teóricas e práticas para manter uma distinção entre público e privado, essa distinção não deve corresponder a uma oposição hierárquica entre razão e sentimento, masculino e feminino, universal e particular.

O sentido básico de público é o que é aberto e acessível. O público, em princípio, não é excludente. Embora seja geral nesse sentido, essa concepção de um público não implica homogeneidade nem a adoção de um ponto de vista geral ou universal. De fato, em espaços e fóruns públicos abertos e aces- 
síveis, devem-se esperar encontrar e ouvir aqueles que são diferentes, cujas perspectivas, experiências e filiações sociais sejam diferentes. Para promover uma política de inclusão, então, os democratas participativos devem promover o ideal de um público heterogêneo, em que as pessoas se destaquem com suas diferenças reconhecidas e respeitadas por outras, embora, talvez, não totalmente compreendidas. O privado, como aponta Hannah Arendt (1958, p. 58-67), está etimologicamente relacionado à privação. Da forma como é tradicionalmente concebido, o privado é aquilo que deve ser escondido da vista ou o que não pode ser dado a ver. Está ligado a vergonha e imperfeição. Como diz Arendt, essa noção do privado implica a exclusão, do público, de aspectos físicos e afetivos da vida humana.

Em vez de defini-lo como aquilo que o público exclui, sugiro, o privado deve ser definido, como em uma das correntes da teoria liberal, como o aspecto da vida e da atividade de qualquer pessoa do qual ela tem direito de excluir outras. O privado, nesse sentido, não é o que as instituições públicas excluem, mas o que o indivíduo escolhe retirar da vista do público. Com o crescimento das burocracias estatais e não estatais, a proteção da privacidade se tornou uma questão pública candente. Na sociedade capitalista de bem-estar, a defesa da privacidade pessoal se tornou não apenas uma questão de manter o Estado fora de certos assuntos mas de exigir regulamentação positiva por parte do Estado para garantir que tanto suas próprias agências quanto organizações não estatais, tais como as empresas, respeitem as demandas de privacidade dos indivíduos.

Essa maneira de formular os conceitos de público e privado, que é inspirada nas confrontações feministas com a teoria política tradicional, não nega sua distinção. Nega, no entanto, uma divisão social entre as esferas pública e privada, cada uma com diferentes tipos de instituições, atividades e atributos humanos. O conceito de público heterogêneo implica dois princípios políticos: (a) nenhuma pessoa, nenhuma ação ou nenhum aspecto da vida de uma pessoa deve ser forçado à privacidade, e (b) nenhuma instituição ou prática social deve ser excluída a priori da condição de tema apropriado para a expressão e a discussão pública.

A concepção moderna do público, já argumentei, cria uma concepção de cidadania que exclui da atenção pública a maioria dos aspectos particulares das pessoas. A vida pública deve ser "cega" em relação a raça, sexo, idade e assim por diante, e todas as pessoas devem entrar em condições idênticas no 
público e em sua discussão. Essa concepção do público resultou na exclusão de pessoas e aspectos de pessoas da vida pública.

Nossa sociedade ainda força pessoas ou aspectos das pessoas à privacidade. A repressão da homossexualidade talvez seja o exemplo mais marcante. Nos Estados Unidos de hoje, a maioria das pessoas parece ter a visão liberal de que as pessoas têm o direito de ser homossexuais, desde que mantenham suas atividades privadas. Chamar a atenção, em público, para o fato de que se é homossexual, fazer demonstrações públicas de afeto homossexual ou até mesmo reivindicar publicamente as necessidades e direitos dos homossexuais provoca ridicularização e medo em muitas pessoas. Nossa sociedade está apenas começando a mudar a prática de manter deficientes físicos e mentais fora da vista do público. Há quase um século, as mulheres “respeitáveis" têm acesso a espaços públicos e expressão pública, mas as normas predominantes ainda nos pressionam a privatizar as manifestações mais evidentes da nossa feminilidade - menstruação, gravidez, lactação - para mantê-las fora do discurso público, da opinião pública e da consideração pública. Por extensão, as crianças devem ser mantidas fora da vista do público e, claro, suas vozes não devem receber expressão pública.

O slogan feminista "o pessoal é político" expressa o princípio de que nenhuma prática ou atividade social deve ser excluída, como tema impróprio para discussão pública, expressão ou escolha coletiva. O movimento contemporâneo de mulheres problematizou publicamente muitas práticas que eram consideradas demasiado triviais ou privadas para discussão pública: o significado dos pronomes, a violência doméstica contra as mulheres, a prática de os homens abrirem portas para as mulheres, o abuso sexual de mulheres e crianças, a divisão sexual do trabalho doméstico e assim por diante.

As políticas socialista e populista requerem a problematização pública de muitas ações e atividades consideradas propriamente privadas, como a forma como indivíduos e empresas investem seu dinheiro, o que produzem e como produzem. A sociedade corporativa do bem-estar permite que diversas grandes instituições cujas ações têm um enorme impacto sobre muitas pessoas definam sua atividade como privada, dando-lhes o direito de excluir outras. Democratas participativos interessados em minar opressões causadas economicamente, como a exploração e a marginalização, geralmente requerem que algumas ou todas as atividades dessas instituições sejam submetidas a decisões públicas democráticas. 
Esses exemplos mostram que o público e o privado não correspondem facilmente a esferas institucionais, como trabalho versus família, ou Estado versus economia. Na política democrática, o ponto onde a linha da privacidade deve ser traçada se torna, em si, uma questão pública (Cunningham, 1987, p. 120). O propósito de proteger a privacidade é preservar as liberdades de ação, oportunidade e participação individuais. A reivindicação de qualquer instituição ou coletivo à privacidade, ao direito de excluir outros, só pode ser justificada como garantia para um alcance justificado da privacidade individual.

Como sugeri no início deste capítulo, desafiar a oposição tradicional entre público e privado, que se alinha com a oposição entre universal e particular, razão e afetividade, implica desafiar uma concepção de justiça que a opõe ao cuidado. Uma teoria que limita a justiça a princípios formais e universais, que definem o contexto em que cada pessoa pode buscar seus objetivos pessoais sem prejudicar a capacidade das outras para ir em busca dos seus, implica não apenas uma concepção muito limitada de vida social, como sugere Michael Sandel (1982), mas uma concepção muito limitada de justiça. Como virtude, a justiça não pode se opor a necessidade, sentimento e desejo pessoais, mas designa as condições institucionais que possibilitam às pessoas satisfazer suas necessidades e expressar seus desejos. As necessidades podem ser expressas em sua particularidade em um público heterogêneo.

\section{Referências}

ADORNO, Theodor (1973). Negative dialectics. New York: Continuum.

ANDERSON, Benedict (1983). Imagined communities: reflections on the origin and spread of nationalism. London: New Left Books.

ARENDT, Hannah (1958). The human condition. Chicago: University of Chicago Press.

BARBER, Benjamin (1984). Strong democracy. Berkeley, Los Angeles: University of California Press.

BENHABIB, Seyla (1986). Critique, norm and utopia. New York: Columbia University Press.

BERMAN, Marshall (1982). Al that is solid melts in the air. New York: Simon \& Schuster

BLUM, Lawrence (1980). Friendship, altruism and morality. London: Routlegde, Kegan Paul. 
(1988). "Gilligan and Kohlberg: implications for moral theory". Ethics, n. 97, p. 472-491.

BUCHANAN, Allen (1982). Marx and justice. Totowa, N. J.: Rowman \& Allanheld.

CUNNINGHAM, Frank (1987). Democratic theory and socialism. Cambridge: Cambridge University Press.

DARWALL, Stephen (1983). Impartial reason. Ithaca: Cornell University Press. DERRIDA, Jacques (1976). Of grammatology. Baltimore: Johns Hopkins University Press.

(1978). "Violence and metaphysic: an essay on the thought of Emmanuel Levinas", em Writing and difference. Chicago: University of Chicago Press.

ELLISON, Charles (1985). "Rousseau and the modern city: the politics of speech and dress". Political Theory, n. 13, p. 497-534.

ELSHTAIN, Jean (1981). Public man, private woman. Princeton: Princeton University Press.

FRIEDMAN, Marilyn (1985). "Care and context in moral reasoning", em HARDING, Carol (ed.). Moral dilemmas: philosophical and psychological issues in the development of moral reasoning. Chicago: Precedent (1987). "Beyond caring: the de-moralization of gender", em HANEN, Marsha \& NIELSEN, Kai (eds.). Science, morality and feminist theory. Calgary: University of Calgary Press.

(1989). "Impracticality of impartiality". Journal of Philosophy, n. 86, p. $645-656$.

GILLIGAN, Carol (1982). In a different voice. Cambridge: Harvard University Press

GLENNON, Lynda (1979). Women and dualism. New York: Longman HABERMAS, Jürgen (1973). Theory and practice. Boston: Beacon. (1974). “The public sphere: an encyclopedia article”. New German Critique, n. 1, p. 49-55.

(1975). Legitimation crisis. Boston: Beacon.

(1981). "New social movements". Telos, n. 49, p. 33-37.

(1983). The theory of communication competence. Vol. 1: Reason and rationalization of society. Boston: Beacon.

(1987). The theory of communication competence. Vol. 2: Lifeworld and system. Boston: Beacon. 
HERZOG, Don (1985). “Some questions for republicans”. Political Theory, p. 14, p. 473-493.

IRIGARAY, Luce (1985). Speculum of the other woman. Ithaca: Cornell University Press.

KEANE, John (1984). Public life in late capitalism. Cambridge: Cambridge University Press.

LANDES, Joan (1988). Women and the public sphere in the age of the French Revolution. Ithaca: Cornell University Press.

LANGE, Lynda (1979). "Rousseau, women and the general will”, em LANGE, Lynda \& CLARK, Lorenne M. G. (eds.). The sexism of social and political theory. Toronto: University of Toronto Press.

LEVINAS, Emmanuel (1969). Totally and infinity. Pittsburgh: Duquesne University Press.

LLOYD, Genevieve (1984). The man of reason: "male and female" in western philosophy. Minneapolis: University of Minnesota Press.

MOSSE, George (1985). Nationalism and sexuality. New York: Fertig.

NAGEL, Thomas (1986). The view from nowhere. Oxford: Oxford University Press

NICHOLSON, Linda (1986). Gender and history. New York: Columbia University Press.

NODDINGS, Nel (1984). Caring: a feminine approach to ethics and moral education. Berkeley: University of California Press.

NOEDLINGER (1981). On the autonomy of the democratic state. Cambridge: Harvard University Press.

OKIN, Susan (1978). Women in western political thought. Princeton: Princeton University Press.

(1982). "Women and the making of the sentimental family". Philosophy and Public Affairs, n. 11, p. 65-88.

(1989). "Reason and feeling in thinking about justice". Ethics, n. 99, p. 229-249.

PATEMAN, Carole (1970). Participation and democratic theory. Cambridge: Cambridge University Press.

(1979). Political obligation. Berkeley: University of California Press. (1986). "Feminism and participatory democracy: some reflections on sexual difference and citizenship". Artigo apresentado à reunião da Western Division da American Philosophical Association, St. Louis, abril. 
(1988). The sexual contract. Stanford: Stanford University Press.

PELCZYNSKI, Zbigniew A. (1971). "The hegelian conception of the state", em PELCZYNSKI, Zbigniew A. (ed.). Hegel's political philosophy: problems and perspectives. Cambridge: Cambridge University Press.

PITKIN, Hannah (1981). "Justice: on relating public and private". Political Theory, n. 9, p. 327-352.

RAWLS, John (1971). A theory of justice. Cambridge: Harvard University Press. SUNSTEIN, Cass R. (1988). "Beyond the republican revival". Yale Law Journal, n. 97, p. 1539-1590.

SANDEL, Michael (1982). Liberalism and the limits of justice. Cambridge: Cambridge University Press.

SENNETT, Richard (1974). The fall of public man. New York: Random House. SHKLAR, Judith (1969). Men and citizens. Cambridge: Cambridge University Press.

SPRAEGENS, Thomas (1981). The irony of liberal reason. Chicago: University of Chicago Press.

TAKAKI, Ronald (1979). Iron cages: race and culture in nineteenth century America. New York: Knopf.

WALTON, Anthony (1983). "Public and private interests: Hegel on civil society and the state", em BENN, Stanley \& GAUS, Gerald (eds.). Public and private in social life. New York: St. Martin's.

WALZER, Michael (1982). "Politics in the welfare state: concerning the role of american radicals", em HOWE, Irving (ed.). Beyond the welfare state. New York: Schocken.

(1987). Interpretations of social criticism. Cambridge: Harvard University Press.

WILLIAMS, Bernard (1985). Ethics and the limits of philosophy. Cambridge: Harvard University Press.

YOUNG, Iris (1981). "Toward a critical theory of justice". Social theory and practice, n. 7, p. 279-302.

(1987). "Impartiality and the civic public: some implications of feminist critiques of moral and political theory", em BENHABIB, Seyla \& CORNELL, Drucilla (eds.). Feminism as critique. Oxford: Polity; Minneapolis: University of Minnesota Press.

(1989). "Polity and group difference: a critique of the ideal of universal citizenship". Ethics, n. 99, p. 250-274. 